Insignia Journal of International Relations

Vol. 7, No. 2, November 2020, 154-173

P-ISSN: 2089-1962; E-ISSN: 2597-9868

\title{
Analisis Respon Vietnam dalam Menghadapi Kebijakan Illegal Fishing Indonesia di Zona Ekonomi Eksklusif Perairan Natuna
}

\author{
Tia Maulida \\ Jurusan Hubungan Internasional, Universitas Pertamina \\ Email: tiamaulidaaa@gmail.com \\ Indra Kusumawardhana \\ Jurusan Hubungan Internasional, Universitas Pertamina \\ Email: kusumawardhana.up@gmail.com
}

\begin{abstract}
Abstrak
Perancangan/penelitian ini tentang respons Vietnam terhadap kebijakan IUU Fishing Indonesia "Sink the Vessels" yang telah menenggelamkan kapal Vietnam sebanyak 321 buah sejak tahun 2014-2019, dengan tujuan untuk memberikan pemahaman mengenai strategi Vietnam dalam mempertahankan hubungannya dengan Indonesia serta respons Vietnam yang tidak agresif terhadap kebijakan tersebut. Penelitian ini menggunakan pendekatan realisme defensif melalui empat asumsi dari Jeffrey W. Taliaferro. Metode yang dipergunakan adalah model penelitian kualitatif yang sifatnya deskriptif dengan teknik pengumpulan data studi kepustakaan melalui informasi dan sumber-sumber terpercaya. Hasil dari penelitian ini menunjukan bahwa berdasarkan empat asumsi dasar realisme Taliaferro ini Vietnam mengalami dilema keamanan yang tidak berfokus hanya kepada Indonesia, melainkan juga didorong karena adanya konflik perairan yang kompleks di kawasan yang didasarkan atas offensedefense balance, kedekatan geografis antara Vietnam dan Indonesia, juga mempengaruhi akses terhadap bahan baku pada negara-negara di sekitar kawasan tersebut, kapabilitas militer Vietnam yang berada dibawah Indonesia serta politik dalam negeri Vietnam telah membawa Vietnam kepada kecenderungannya untuk tetap menjaga hubungan baik dengan Indonesia. Bagaimanapun dalam menyikapi konflik yang terjadi antar dua negara atau lebih harus di dasarkan pada banyak aspek, baik dari aspek hubungan international dengan pendekatan teoriteori terkait, serta aspek lainnya yang secara tidak langsung berhubungan dengan geografis, ekonomi dan perdagangan, politik dan keamanan, sejarah, sosial dan budaya, power/kekuatan serta kondisi sistem global secara keseluruhan.
\end{abstract}

Kata Kunci: kebijakan IUUF, realisme defensif, respons Vietnam, Sink the Vessels

\begin{abstract}
This design / research on Vietnam's response to the IUU Fishing Indonesia "Sink the Vessels" policy which has sunk as many as 321 Vietnamese vessels from 2014-2019, aims to provide an understanding of Vietnam's strategy in maintaining its relationship with Indonesia and Vietnam's non-aggressive response towards the policy. This study uses a defensive realism approach through four assumptions from Jeffrey $W$. Taliaferro. The method used is a qualitative research model that is descriptive with literature study data collection techniques through information and reliable sources. The results of this study indicate that based on the four basic assumptions of Taliaferro's realism, Vietnam is experiencing a security dilemma that is not focused solely on Indonesia, but is also encouraged due to complex water conflicts in the region based on offense-defense balance, geographical proximity between Vietnam and Indonesia, also affects access to raw materials in countries around the region, Vietnam's military capabilities under Indonesia and Vietnam's domestic politics have brought Vietnam to its tendency to maintain good relations with Indonesia. However in dealing with conflicts that occur between two or more countries must be based on many aspects, both from the aspect of international relations with the approach of related theories, as well as other aspects that are indirectly related to geographical, economic and trade, politics and security, history, social and cultural, power and the overall condition of the global system.
\end{abstract}

Keywords: IUUF "Sink the Vessels" policy, defensive realism, Vietnamese response 


\section{PENDAHULUAN}

Keberadaan Vietnam di dunia internasional semakin menarik, sejak menjadi bagian dari salah satu negara yang terlibat pada sengketa Laut China Selatan. Laut China Selatan sendiri merupakan satu dari beberapa jalur laut internasional yang digunakan untuk kepentingan berbagai negara di wilayah Asia Tenggara. Wilayah ini memiliki kekayaan laut yang melimpah sehingga tidak hanya perdagangan dan navigasi laut tetapi wilayah ini juga duntuk kegiatan eksplorasi maupun eksploitasi sumber daya alam. Sejak terlibatnya Vietnam pada konflik di daerah tersebut, kondisi dan keadaan perairan laut Vietnam menjadi tidak stabil. Hal tersebut diperparah lagi dengan penerapan kebijakan illegal, unreported, unregulated fishing (IUUF) "sink the vessels" atau STV oleh Indonesia, terhadap penangkapan ikan secara ilegal yang dilakukan oleh beberapa kapal Vietnam dan berujung dengan tindakan penenggelaman kapal. IUUF merupakan istilah luas yang digunakan untuk berbagai kegiatan penangkapan ikan yang ditemukan di semua jenis dan dimensi perikanan, ini terjadi baik di laut lepas maupun di wilayah dalam yurisdiksi nasional. Ini menyangkut semua aspek dan tahapan penangkapan dan pemanfaatan ikan, dan terkadang terkait dengan kejahatan terorganisir (FAO, 2019).

Penerapan kebijakan Indonesia dilakukan berdasarkan hukum nasional dan hukum internasional yang merujuk pada UU No. 32 Tahun 2014 tentang Kelautan. Definisi kelautan dalam undang-undang ini adalah segala hal yang berhubungan dengan laut dan/ atau kegiatan di wilayah laut yang meliputi dasar laut dan tanah di bawahnya, kolom air dan permukaan laut, termasuk wilayah pesisir dan pulau-pulau. Bagi Indonesia, tindakan penenggelaman kapal yang dilakukan ini merupakan upaya perlindungan lingkungan laut, sumber daya alam, dan kedaulatan negara. Begitu juga mengenai perikanan, yang diatur dalam Undang-Undang No. 45 Tahun 2009 tentang
Perikanan (UU Perikanan), dan United Nations on the Law of the Sea (UNCLOS) yang telah diratifikasi dengan UU No. 17 Tahun 1985 (Elnizar, 2017).

Menurut Undang-undang Nomor 45 Tahun 2009 tentang Perikanan Pasal 69 ayat (1) dan (4) menyatakan:

“(1) Kapal Pengawas perikanan berfungsi melaksanakan pengawasan dan penegakan hukum dibidang perikanan dalam wilayah pengelolaan perikanan Negara Republik Indonesia. (4) Dalam melaksanakan fungsi sebagaimana dimaksud pada ayat (1) penyidik dan/atau pengawas perikanan dapat melakukan tindakan khusus berupa pembakaran dan/atau penenggelaman kapal perikanan yang berbendera asing berdasarkan bukti permulaan yang cukup."

Sejalan dengan kebijakan IUUF yang diberlakukan di Indonesia, hal terpenting dalam penegakkan hukum di laut adalah dengan implementasi terhadap UU No. 45/2009 tentang perikanan yang terkait kepada penenggelaman kapal-kapal ikan ilegal. Dari data yang telah didapat, jumlah penenggelaman kapal pelaku illegal fishing sejak tahun 2014 sampai dengan tahun 2019 adalah sebanyak 556 kapal, dengan rincian bahwa 26 buah Kapal Ikan Indonesia (KII) dan 530 buah Kapal Ikan Asing (KIA). Dari keseluruhan 463 buah KIA tersebut, kapal berbendera Vietnam berjumlah 321 buah, pada periode tahun 2014 hingga tahun 2019 (Laporan KKP, 2019 : 171 ). Berikut ini adalah rekapitulasi jumlah KII dan KIA yang ditenggelamkan dari tahun 2014 hingga 2019. 
Tabel 1.

Jumlah Penenggelaman Kapal Pelaku Illegal Fishing dan Data Pemusnahan Barang Bukti/Barang Rampasan Negara pada Periode Tahun 2014-2019

\begin{tabular}{clccccccc}
\hline No. & \multicolumn{1}{c}{ Negara } & $\mathbf{2 0 1 4}$ & $\mathbf{2 0 1 5}$ & $\mathbf{2 0 1 6}$ & $\mathbf{2 0 1 7}$ & $\mathbf{2 0 1 8}$ & $\mathbf{2 0 1 9}$ & Jumlah \\
\hline 1. & Malaysia & - & 12 & 27 & 12 & 22 & 16 & 89 \\
\hline 2. & Filipina & 1 & 35 & 22 & 17 & 15 & 1 & 91 \\
\hline 3. & Vietnam & 3 & 36 & 50 & 91 & 83 & 49 & 321 \\
\hline 4. & Indonesia & - & 10 & 5 & 6 & 4 & 1 & 26 \\
\hline 5. & Thailand & 2 & 19 & - & 1 & 1 & 1 & 24 \\
\hline 6. & Papua Nugini & 2 & - & - & - & - & - & 2 \\
\hline 7. & Tiongkok & - & 1 & - & - & - & - & 1 \\
\hline 8. & Nigeria & - & - & 1 & - & - & - & 1 \\
\hline 9. & Belize & - & - & 1 & - & - & - & 1 \\
\hline & Total & $\mathbf{8}$ & $\mathbf{1 1 3}$ & $\mathbf{1 1 5}$ & $\mathbf{1 2 7}$ & $\mathbf{1 2 5}$ & $\mathbf{6 8}$ & $\mathbf{5 5 6}$ \\
\hline
\end{tabular}

Sumber: Laporan Kinerja Kementerian Kelautan dan Perikanan, 2019.

Kebijakan STV yang diterapkan oleh Indonesia adalah merupakan suatu bentuk rangkaian kebijakan yang bersifat kontroversial. Pelaksanaan kebijakan ini oleh otoritas perikanan Indonesia telah mengakibatkan terjadinya penenggelaman kapal berbendera Vietnam sebanyak 321 buah, serta penangkapan terhadap awak kapal yang terkait dengan kegiatan ilegal tersebut. Sejumlah kapten dan kru kapal pun ditahan di Indonesia atas tindakan pidana yang berupa pelanggaran terhadap kebijakan tersebut, baik penangkapan ikan tanpa izin, penggunaan izin palsu, serta penangkapan ikan dengan menggunakan alat tangkap yang dilarang hingga penangkapan jenis ikan yang dilarang.

Menurut data dari Department for Structural and Cohesion Policies DirectorateGeneral for Internal Policies, Vietnam, yang ditulis pada Oktober 2018, Vietnam memiliki kurang lebih 110.000 yang beroperasi sebagai kapal penangkap ikan, dan dari keseluruhan kapal-kapal tersebut hanya sejumlah kurang lebih 33.000 buah kapal yang memiliki kapasitas $90 \mathrm{CV}$ atau lebih (Ojamaa, 2018: 21). Dari kondisi tersebut dapat dikatakan bahwa jumlah kapal yang ditenggelamkan oleh Indonesia hanya setara dengan $0,2 \%$ dari keseluruhan kapal penangkap ikan yang dioperasikan oleh Vietnam. Dengan jumlah persentase yang sangat rendah ini dapat disimpulkan bahwa tindakan Vietnam terhadap kebijakan STV Indonesia bersifat defensif.

Seorang pengacara yang mewakili sejumlah kapten kapal negara Vietnam yang ditahan oleh Indonesia bernama Ha Hai dari Asosiasi Advokat Ho Chi Minh City menyatakan bahwa dari sudut pandang Vietnam, kapal-kapal yang ditangkap oleh pihak Indonesia, sebenarnya masih berada di perairan Vietnam. Hai menyatakan bahwa tindakan Indonesia yang kerap kali berulang menahan kapal ikan Vietnam merupakan tindakan yang salah, karena kapal-kapal Vietnam tersebut masih beroperasi dalam perairan Vietnam dan bukan berada di perairan yang dipersengketakan (BBC, 2018). Namun demikian, pemerintah Vietnam menghindari tindakan secara agresif terhadap kebijakan pemerintah Indonesia tersebut.

Dalam beberapa interaksi bilateral kedua negara, Vietnam berusaha 
mengangkat masalah ini sebagai isu penting dari keseluruhan hubungan perdagangan antara kedua negara. Pada bulan November 2014, duta besar Vietnam untuk Indonesia, Nguyen Xuan Thuy, bertemu dengan Susi Pudjiastuti untuk membahas permasalah ini. Dari hasil pertemuan tersebut, pihak Hanoi menyatakan bahwa Vietnam akan lebih mendidik nelayannya untuk berusaha tunduk kepada hal-hal terkait dengan undang-undang dan peraturan perikanan (Parameswaran, 2015).

Pada bulan April 2015, Perdana Menteri Nguyen Tan Dung juga bertemu dengan Menteri Luar Negeri Indonesia, Retno Marsudi. Dalam kunjungannya itu, Nguyen Tan Dung mengungkapkan harapannya terhadap Indonesia agar dapat memperlakukan nelayan dan kapal nelayan Vietnam atas dasar semangat persahabatan. Pada tanggal 20 Agustus 2015, juru bicara Kementerian Luar Negeri Hanoi, Le Hai Binh menyatakan kekhawatirannya akan penenggelaman kapal yang dilakukan Indonesia terhadap kapal-kapal Vietnam di perairan Indonesia. Binh mengatakan bahwa Vietnam telah mengirimkan nota diplomatik kepada pemerintah Indonesia yang berisikan tentang rekomendasi kepada pihak Jakarta agar dapat memperhatikan kemitraan strategis kedua negara dalam berurusan dengan para nelayan Vietnam (Parameswaran, 2015).

Berdasarkan pemahaman di atas, fokus utama yang akan dikaji dalam tulisan ini akan berfokus pada pemahaman dari respons yang dilakukan Vietnam terhadap kebijakan IUUF Indonesia STV. Pada penelitian sebelumnya dapat ditemukan dalam artikel yang ditulis oleh Rusadi Kantaprawira, Arry Bainus, dan Indra Kusumawardhana yang dimuat dalam Journal of ASEAN Studies: The Unbreakable Relations between Indonesia-Vietnam Under "Sink the Vessels" Policy: A Complex Systems Approach. Penulis menjelaskan bahwa ditengah polemik dan ketegangan yang terjadi antara Indonesia dan Vietnam, hubungan kedua negara jauh dari kata bermusuhan. Dalam artikel tersebut, penulis menjelaskan melalui Foreign Policy Action dan Complex Systems Approach yang terdiri dari simbol, kepentingan dan peran dari sistem yang menjadi alasan dibalik hubungan baik kedua negara tersebut meskipun dalam ketegangan di lautan (Kantapawira, Bainus \& Kusumawardhana, 2018: 157).

Penelitian selanjutnya dapat ditemukan dalam artikel yang ditulis oleh Mansur Juned, Galby Rifqi Samhudi dan Rahmat Aming Lasim yang dimuat dalam International Journal of Multicultural and Multireligious Understanding: The Impact Indonesia's Sinking of Illegal Fishing Ships on Major Southeast Asia Countries. Penulis menjelaskan melalui pendekatan neoclassical realism dari Gideon Rose yang di dalamnya menyatakan bahwa tekanan sistemik dapat datang dari satu negara dan berdampak terhadap satu regional atau dapat diartikan bahwa kebijakan suatu negara akan memberikan dampak kepada negara-negara lain dalam satu kawasan, sebagai contoh adalah kebijakan IUUF STV oleh Indonesia yang mempengaruhi hubungan bilateral dengan negara-negara dalam satu kawasan, termasuk Vietnam (Juned, Samhudi, \& Lasim, 2019: 64).

Sementara itu pada penelitian kali ini terdapat kebaruan dalam penelitian ini yakni penulis akan berfokus pada pemahaman dari respons yang dilakukan Vietnam terhadap kebijakan IUUF Indonesia STV melalui empat asumsi realisme defensif, serta menganalisis lebih konkrit dinamika dan polemik atas situasi yang dapat mempengaruhi hubungan negara-negara di kawasan. Pertanyaan utama yang diajukan oleh artikel ini adalah mengapa Vietnam merespons kebijakan IUUF STV Indonesia secara tidak agresif?. Dengan menggunakan pendekatan realisme defensif, tulisan ini mengargumentasikan empat asumsi yang melandasi respons Vietnam kepada Indonesia yang terdiri dari dilema keamanan, pengubah struktural, 
kapabilitas material dan politik dalam negeri.

\section{Kerangka Pemikiran Pendekatan Real- isme Defensif}

Realisme defensif akan menjadi teori utama yang digunakan untuk menganalisis alasan dari respons Vietnam terhadap Indonesia. Realisme merupakan salah satu pendekatan dalam hubungan internasional yang memiliki pengertian sangat beragam. Namun pada umumnya, realisme memiliki asumsi yang sama tentang pentingnya power dalam dunia internasional. Realisme menekankan bahwa kendala yang timbul pada dunia politik didasarkan pada sifat dasar manusia dalam hubungannya dengan tidak adanya pemimpin dalam sistem pemerintahan secara internasional (Donnelly, 2000: 9).

Bagi realisme defensif, tujuan utama negara adalah bertahan hidup dan memperoleh keamanan. Power merupakan alat untuk mencapai tujuan dan bukan merupakan tujuan itu sendiri. Menurut Jeffrey W. Taliaferro, realisme defensif berpendapat bahwa sistem internasional hanya akan memberikan insentif untuk ekspansi pada kondisi tertentu. Di bawah sistem internasional yang anarki, banyak cara yang digunakan negara untuk meningkatkan keamanannya dan mengurangi keamanan negara lain. Dilema inilah yang menyebabkan kondisi antar negara yang tidak aman berkenaan dengan ancaman kekuatan atau power antar negara di masa yang akan datang (Taliaferro, 2015: 129).

Realisme defensif berasal dari empat asumsi tambahan yang menjelaskan bagaimana variabel struktural membentuk hasil internasional dan kebijakan luar negeri suatu negara, seperti yang dikatakan oleh Talliaferro dalam jurnalnya yang berjudul Security Seeking Under Anarchy: Defensive Realism Revisited:

"I argue that defensive realism proceeds from four auxiliary assumptions that specify how structural variables translate into international outcomes and state's foreign policies" (Taliaferro, 2015: 131).

Asumsi pertama menyatakan bahwa dilema keamanan merupakan fitur yang tidak bisa dihindari dari sistem internasional yang anarki. Asumsi kedua adalah pengubah struktur, dalam hal ini contohnya seperti offense-defense balance, kedekatan geografis, dan akses terhadap bahan baku yang akan mempengaruhi tingkat keparahan dilema keamanan diantara negara-negara yang terlibat. Asumsi yang ketiga, menyatakan bahwa kekuatan material akan mendorong kebijakan luar negeri suatu negara melalui media perhitungan dan persepsi dari para pemimpinnya. Yang terakhir, politik dalam negeri dapat membatasi efisiensi dari respon suatu negara terhadap lingkungan eksternalnya (Taliaferro, 2015: 131).

\section{Metode Penelitian}

Penelitian ini menggunakan jenis penelitian kualitatif yang bersifat deskriptif. Dalam mengkaji penelitian ini, penulis menggunakan metode kualitatif. Metode kualitatif, diartikan sebagai sebuah metode dalam penelitian yang sifatnya deskriptif, menggunakan analisis, dan mengacu pada data, serta menggunakan teori yang ada sebagai bahan pendukung. Metode yang digunakan untuk mengeksplorasi atau memahami suatu masalah, baik individu maupun kelompok, yang berkaitan dengan suatu masalah sosial. Metode kualitatif mengandalkan data teks dan gambar dan memiliki langkah unik dalam analisis data (Creswell, 2013: 183). Penelitian ini kemudian dianalisis secara deduktif untuk memahami suatu fenomena secara lebih khusus. Sumber data dalam penelitian adalah sumber data sekunder berupa datadata yang diambil melalui literatur terkait dengan tema IUU Fishing "Sink the Vessels" khususnya di Indonesia dan Vietnam, datadata resmi pemerintah baik berupa statistik maupun dalam bentuk laporan atau penjelasan, artikel-artikel dan jurnal ilmiah 
serta data tambahan lainnya yang relevan dengan penelitian ini.

\section{HASIL DAN PEMBAHASAN}

Dilema Keamanan Vietnam di Asia Tenggara yang Mempengaruhi Respons Vietnam Terhadap Kebijakan Indonesia

Menurut Taliaferro, dalam teori defensif realisme, dilema keamanan tidak dapat terhindarkan dari sistem internasional yang anarki. Kebijakan yang dibuat Vietnam untuk merespon kebijakan IUUF Indonesia tidak terlepas dari adanya faktor eksternal dari pihak negara lain yang berada dalam regional tersebut. Sebagai contoh, saat ini, interaksi Vietnam pada sengketa Laut China Selatan turut melibatkan beberapa negara Asia Tenggara dan Asia Timur antara lain, China, Taiwan, Vietnam, Thailand, Filipina, Kamboja, Malaysia, dan Singapura, dimana terdapat klaim dari negara-negara tersebut pada sebagian wilayah Indonesia.

Gesekan-gesekan yang terjadi saat ini telah menimbulkan sengketa antarnegara yang memiliki kepentingan pada wilayah tersebut, khususnya China yang secara tegas telah mengklaim bahwa daerah yang secara internasional ditetapkan sebagai Zona Ekonomi Ekslusif (ZEE) milik negara lain adalah merupakan wilayahnya. Sementara itu, hampir semua negara kawasan, salah satunya Vietnam, memandang bahwa kehadiran China di wilayah tersebut merupakan ancaman terhadap kebebasan pergerakan di perairan internasional, begitu pula terhadap beberapa negara lainnya yang terlibat langsung dengan sengketa wilayah/ maritim dengan China (Wivell, 2015).

China mengklaim bahwa lebih dari 95\% wilayah Laut China Selatan adalah wilayahnya dan secara langsung menjadikan kawasan tersebut sebagai kawasan pengendali pasokan $85 \%$ impor minyak mentahnya. Diketahui bahwa perairan pada wilayah tersebut tidak hanya berperan untuk kepentingan China saja tetapi selama berabad-abad perairan tersebut telah memegang kendali penting untuk keberlangsungan ekonomi beberapa negara sekitarnya, antara lain: Vietnam, Brunei, Malaysia dan Filipina. Dari keseluruhan negara-negara tersebut, hanya China lah yang memiliki kekuatan terbesar, dan mampu melakukan proyeksi kekuatan global, sedangkan negara lain yang turut terlibat dalam klaim terhadap wilayah tersebut tidak memiliki kapasitas militer yang cukup kuat untuk melakukan perlawanan terhadap klaim yang dinyatakan oleh China (Wivell, 2015).

Dalam sengketa wilayah regional Asia Tenggara ini, beberapa negara termasuk Vietnam mengalami dilema keamanan. Mereka menyatakan bahwa hal tersebut merupakan suatu bentuk ancaman terhadap kepentingan negara-negara tersebut. Namun, mereka tidak bisa secara langsung mengantisipasi dengan meningkatkan persenjataan militer agar sanggup melakukan perlawanan atau tekanan terhadap pihak China, melainkan perlu memikirkan strategi lain dalam menghadapi sengketa wilayah ini. Dinamika persenjataan militer yang berlangsung saat ini di Asia Tenggara adalah merupakan hal yang penting untuk dibahas dalam pokok permasalahan kali ini.

Dilema keamanan yang dialami Vietnam tercermin pula dalam Buku Putih Pertahanan Vietnam yang menilai bahwa situasi global berevolusi dengan cepat menuju tatanan multipolar dan Wilayah Asia-Pasifik, termasuk Asia Tenggara, yang menjadi pusat pengembangan yang dinamis dan menempati lokasi geoekonomi, geopolitik, dan geostrategis yang semakin penting (Thu, 2019). Meskipun tidak menyebut nama China, jelas bahwa buku putih mencerminkan kekhawatiran perambahan China. Persaingan kekuatan besar secara bertahap menciptakan dilema bagi Vietnam sehubungan dengan keseimbangan strategisnya. Ahli strategi Vietnam berbicara tentang kebijakan yang tidak memihak satu negara terhadap yang lain, tidak ada pangkalan militer asing, dan 
tidak menggunakan kekuatan atau mengancam untuk menggunakan kekuatan dalam hubungan internasional, tetapi, tergantung pada keadaan dan kondisi tertentu, Vietnam akan mempertimbangkan pengembangan hubungan pertahanan dan militer yang diperlukan dan sesuai dengan negara lain (Ministry of National Defence, 2019).

Bila dilihat dari kebijakan militernya, Vietnam dan beberapa negara kawasan Asia Tenggara atau yang disebut dengan ASEAN (Association of South East Asian Nations) telah berusaha untuk tidak mengarahkan konflik kepada tindakan yang bersifat agresif. Berdasarkan pada persentase biaya pembelanjaan sektor militer terhadap Gross
Domestic Product (GDP) yang mengalami kondisi stagnan dan bahkan cenderung mengalami penurunan, dapat digambarkan bahwa negara-negara ASEAN lainnya bukan merupakan ancaman yang serius bagi Vietnam. Data menunjukkan bahwa alokasi anggaran militer Vietnam relatif konsisten dari tahun ke tahun, yaitu 2,28 \% pada tahun 2014, meningkat sedikit pada tahun 2015 sebesar 2,36 \%, dan mengalami sedikit penurunan pada tahun 2017, menjadi $2,26 \%$, serta 2,29 \% pada tahun 2018. Gambar 1 di bawah ini menunjukkan kondisi anggaran militer negeri-negara ASEAN dalam persentasenya terhadap GDP, termasuk negara China.

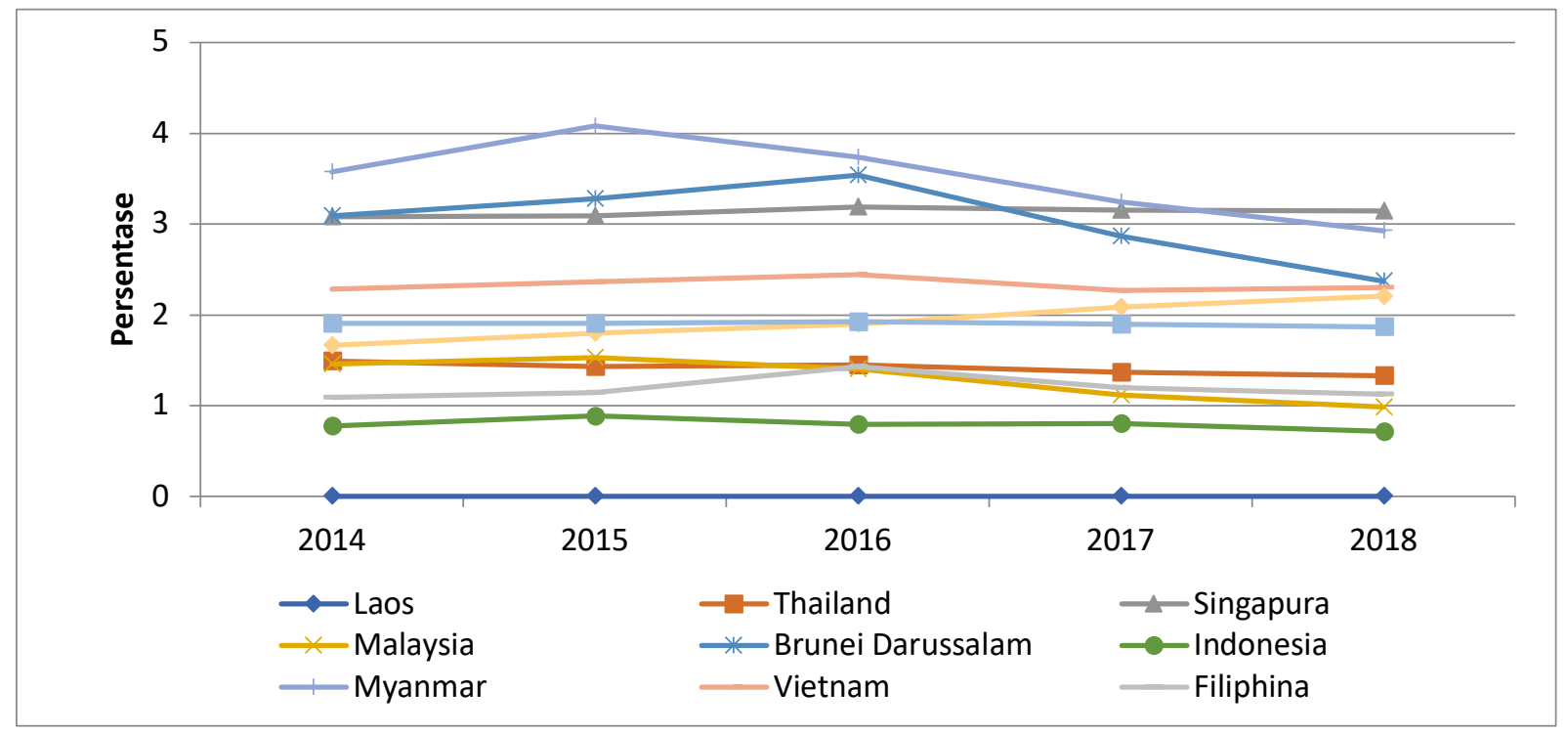

Sumber: Diolah oleh Penulis dari The Stockholm International Peace Research Institute, 2018.

Gambar 1.

Grafik Anggaran Militer Negara ASEAN + China Tahun 2014-2018 (\% of GDP)

Dari data di atas, rata-rata persentase anggaran militer negara-negara ASEAN terhadap GDP mengalami peningkatan, hanya saja belum sebanding dengan peningkatan anggaran militer China yang cukup besar. Jika dilihat melalui persentase tersebut, China memiliki anggaran yang relatif cukup besar. Hal ini telah menimbulkan kekhawatiran dari negara- negara tetangganya. Kekhawatiran yang dialami negara-negara kawasan tersebut bukanlah terhadap besaran anggarannya akan tetapi terhadap pembelanjaan yang dilakukan oleh China.

Dalam gambar 2 di bawah ini, dapat dilihat bahwa pada kurun waktu empat tahun terakhir, hampir seluruh negaranegara di Asia Tenggara telah melakukan 
peningkatan anggaran belanja militernya. Peningkatan kekuatan militer di negaranegara kawasan tersebut tidak terjadi dengan sendirinya, akan tetapi didasari oleh faktor-faktor yang menjadi penggerak ke arah peningkatan tersebut. Beberapa faktor penggerak tersebut antara lain adanya ketegangan regional, kebutuhan proyeksi kekuatan baru, serta adanya pergeseran aktivitas militer dari Amerika Serikat ke Asia, serta kehadiran Tiongkok di Laut China Selatan (Muhamad, 2014: 6). Meskipun didasari atas faktor penggerak lain tersebut, peningkatan militer negaranegara di Asia Tenggara akan berdampak terhadap dilema keamanan Vietnam, seperti yang di sebutkan dalam kalimat berikut:

"Since arms races usually emerge as an impact to threat perception the elevate security dilemma among the conflicting countries, the increase of military expenditure can create a detrimental effect because it could be perceived as preliminary sign as some organized preparations for war (Kantaprawira, Bainus \& Kusumawardhana, 2018: 172)".

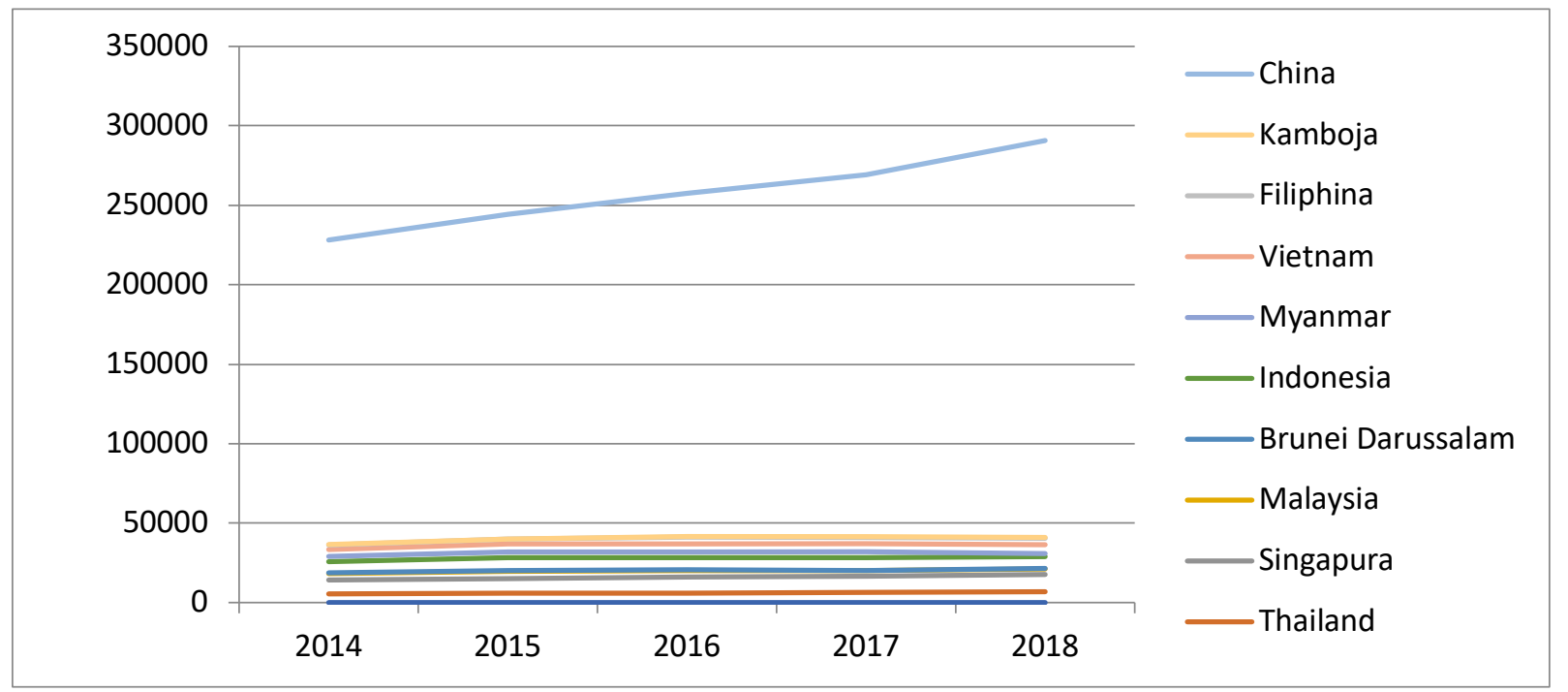

Sumber: Diolah oleh penulis dari The Stockholm International Peace Research Institute Database Online, 2018.

Gambar 2.

Grafik Anggaran Militer Negara ASEAN + China 2014-2018 (dalam juta dollar AS)

Pada tahun 2018, negara-negara ASEAN seperti Thailand menganggarkan biaya militer sebesar $\$ 6.829 .203$, Singapura sebesar \$10.841.000, Filipina sebesar \$3.769.741, Myanmar sebesar \$2.030.465, Malaysia sebesar $\$ 2.030 .465$, Laos sebesar \$22.677, sedangkan Kamboja sebesar \$543.205, dan Brunei Darussalam sebesar \$346.588. Sementara itu, Vietnam berada pada urutan ke-5, dengan nilai anggaran militer sebesar $\$ 5.500 .000$ dan Indonesia di posisi ke-3 dengan military expenditure sebesar \$7.437.197. Dapat disimpulkan bahwa, dibandingkan dengan negara- negara ASEAN, China menempati posisi yang berada jauh diatas Vietnam dan negara-negara ASEAN lainnya, dengan military expenditure sebesar $\$ 249.996 .900$.

Dari kondisi tersebut, beberapa negara Asia Tenggara, khususnya Vietnam, berupaya untuk menghindari terjadinya konflik militer dengan pihak China. Dalam kasus memanasnya hubungan Vietnam dan China di Laut China Selatan, pihak pemerintah China telah mendesak Hanoi untuk menarik ancaman hukumnya pada arbitrase internasional terkait perselisihan teritorial kedua negara. Meskipun demikian 
China tetap berupaya untuk menghindari konflik, dengan meminta kepada Vietnam untuk menghindari tindakan yang dapat merusak perdamaian dan stabilitas keamanan di Laut China Selatan, serta tetap menjaga hubungan bilateral antar kedua negara (Lintner, 2019).

Dari hasil ketetapan pengadilan arbitrase permanen yang berpusat di Den Haag, peta "nine dash line" China yang menggambarkan klaim yang mencakup hampir 90\% dari Laut China Selatan tidak memiliki keabsahan di bawah hukum internasional, termasuk UNCLOS. Meskipun China telah menandatangani dan meratifikasi UNCLOS, China dengan tegas menolak keputusan itu (Lintner, 2019). Sejalan dengan yang dikatakan oleh Rusadi Kantaprawira, Arry Bainus dan Indra Kusumawardhana bahwa ancaman yang terkait dengan integritas teritorial yang dihadapi vietnam terkait dengan perselisihan di Laut China Selatan akan berpotensi memicu konflik terbuka dan lebih besar antara Vietnam dan pemerintah China. Oleh karena itu, pada konteks yang lebih luas, Vietnam menganggap keberadaan UNCLOS menjadi sangat penting, terutama sebagai dasar untuk mendefinisikan suatu rujukan terhadap masalah sengketa di wilayah Laut China selatan (Kantapawira, Bainus \& Kusumawardhana, 2018: 166).

Dari penjelasan di atas, dapat ditarik benang merah bahwa benar adanya jika dilema keamanan tidak dapat dihilangkan dari sistem internasional yang anarki, dan hal ini dapat terlihat secara tidak langsung pada posisi Vietnam yang berada pada kondisi dilema keamanan tersebut. Dalam kondisi dilema keamanan yang demikian, sejumlah negara berupaya untuk tetap bersikap rasional demi mengamankan kepentingan nasionalnya, atau dengan kata lain, bahwa persepsi ancaman khususnya ancaman militer terhadap negara lain, sangat mempengaruhi perilaku Vietnam terhadap Indonesia, begitu pula negaranegara ASEAN lainnya di kawasan.
Peningkatan belanja militer IndonesiaVietnam mengalami peningkatan yang cukup signifikan dalam beberapa tahun terakhir. Perlombaan senjata ini muncul sebagai dampak persepsi ancaman yang meningkat pada dilema keamanan di antara negara-negara yang bertikai sedangkan peningkatan pengeluaran militer ini akan mengakibatkan efek yang merugikan, karena akan dipandang sebagai upaya awal dalam persiapan terjadinya konflik peperangan.

Analisis di atas menunjukkan bahwa dalam sistem yang ada di kawasan perairan Asia Tenggara, Indonesia bukanlah satusatunya dilema keamanan yang sesungguhnya dari Vietnam, melainkan China. Analogi ini dapat dijelaskan untuk menggambarkan kondisi Vietnam dalam merespons kebijakan penenggelaman kapal oleh Indonesia. Jika Vietnam merespons secara keras kebijakan Indonesia ini, maka China memiliki kesempatan untuk lebih menekan Vietnam dalam konstelasi Laut China Selatan. Berdasarkan alasan tersebutlah maka Vietnam tetap menjaga hubungan baiknya dengan Indonesia, agar pihak China tidak dapat melakukan penekanan terhadap Vietnam yang berujung terhadap klaim atas batas wilayah garis putus-putus China.

\section{Pengubah Struktural dalam Dilema Keamanan Vietnam}

Pengubah struktur yang dimaksud pada bagian ini adalah offense-defense balance, kedekatan geografis, dan akses terhadap bahan baku dalam pengaruhnya terhadap tingkat keparahan dilema keamanan antara negara-negara tertentu (Taliaferro, 2015 : 131). Pertama, offensedefense balance menawarkan pandangan optimis tentang politik internasional berdasarkan pada argumen bahwa perang dapat dicegah apabila defense mengungguli dominasi offense. Selain itu teori ini juga berpendapat bahwa kontrol senjata yang efektif dapat mengurangi risiko perlombaan senjata dan perang (Glaser \& 
Kaufman, 1998: 1). Apabila defense lebih menguntungkan negara, langkah yang lebih baik adalah menjaga dari serangan musuh dan mempertahankan sumber daya yang dimiliki daripada melakukan serangan atau ekspansi (Jervis, 1978: 187). Merujuk pada argumen tersebut, pada analisis ini akan memposisikan Vietnam sebagai defender dalam dinamika Asia Tenggara khususnya di dalam ketegangan yang terjadi antara Vietnam dan Indonesia.

Negara dapat berubah menjadi agresor apabila negara tetangga terlebih dahulu melakukan sikap agresif (Alghifari \& Letticia, 2016: 23). Hal ini dapat dilihat pada sengketa Laut China Selatan yang memperlihatkan perilaku China untuk terus meningkatkan kapabilitas militernya dalam usahanya untuk meningkatkan pengaruhnya di kawasan yang strategis dan kaya akan sumber daya alam ini. Dalam sengketa Laut China Selatan, kondisi Vietnam semakin diperparah dengan tindakan agresif Indonesia khususnya terhadap kebijakan penenggelaman pelaku illegal fishing. Perilaku ini dilihat oleh Vietnam sebagai tindakan agresif oleh China dan Indonesia dalam mendominasi kawasan. Oleh karena itulah, Vietnam memainkan perannya sebagai defender yang bersifat defensif untuk tetap menghindari konflik yang akan semakin memanas serta sebagai balance terhadap kawasan Asia Tenggara. Gambar 1 di bawah ini memperlihatkan kondisi tersebut.

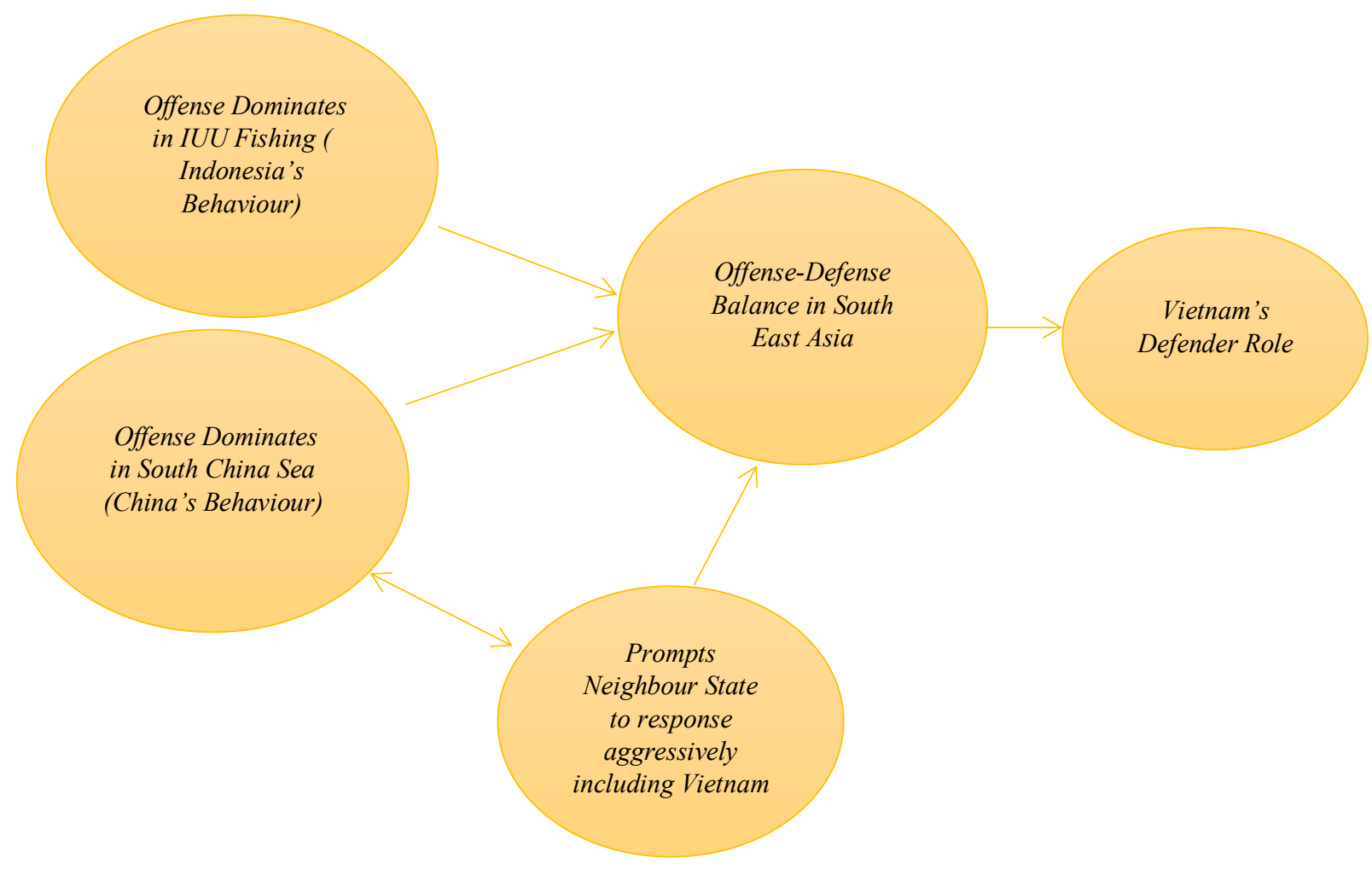

Sumber: Diolah oleh Penulis.

Gambar 3.

Operational Offense-Defense di Kawasan Asia Tenggara

Kedua, letak geografis sangat mempengaruhi hubungan antara Vietnam dan Indonesia. Sebagai contoh, dari beberapa wilayah perairan Indonesia, Laut Natuna Utara di Provinsi Kepulauan Riau menjadi tempat yang favorit untuk melakukan penangkapan ikan. Letak geografis Laut Natuna telah menjadikannya sebagai wilayah yang sangat penting dan strategis bagi negara-negara tetangga 
sekitarnya, termasuk Vietnam (Ambari, 2019). Faktor kedekatan geografis ini, akan selalu dapat memicu konflik kedua negara tersebut, terutama dalam hal perairan dan yang berhubungan dengan batas ZEE. Konflik tersebut mungkin dapat menjadi lebih parah, jika tidak ada kesepakatan ZEE antar keduanya. Sesuai dengan pernyataan yang dikemukakan oleh Lidya Sinaga yang dikutip oleh Callistasia Wijaya bahwa "Konflik di perairan Natuna berpotensi terus berulang selama Indonesia dan Vietnam tidak mencapai kesepakatan terkait batas Zona Ekonomi Eksklusif (ZEE) (Wijaya, 2009)".

Mengacu pada sengketa teritorial di Laut China Selatan, penting untuk dipahami bahwa banyak sumber daya alam yang dipertaruhkan di wilayah tersebut, seperti yang terlihat pada gambar 4. Pada gambar tersebut, terlihat jelas bahwa Vietnam memiliki klaim pada wilayah Laut China Selatan terhadap klaim yang dinyatakan oleh China. Hal ini ditunjukkan dengan nine dash line di bawah ini.

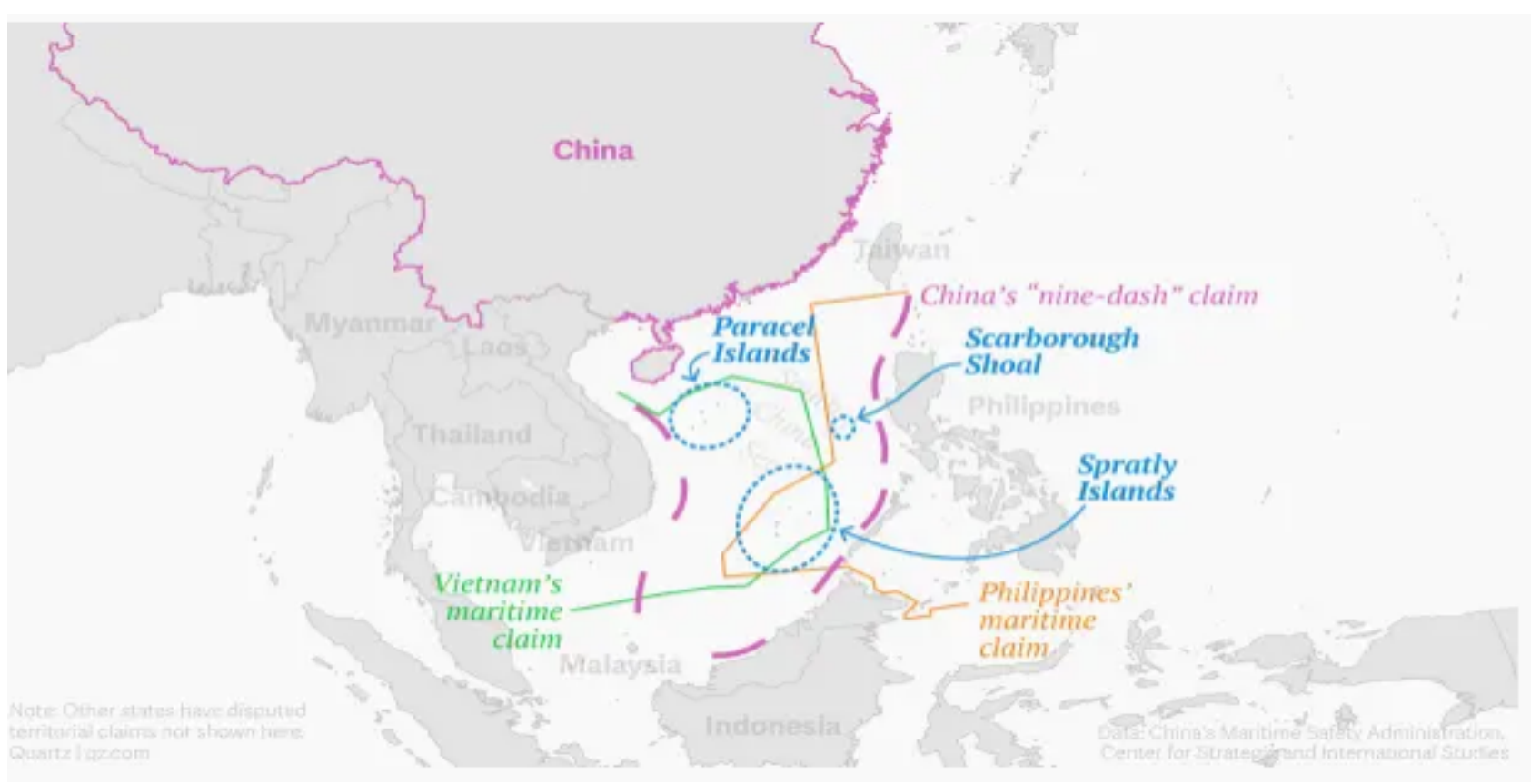

Sumber: Li dalam Quartz, 2019.

Gambar 4.

Peta Laut China Selatan

Terlihat pada gambar tersebut di atas, bahwa hubungan bilateral antara Vietnam dan Indonesia terus didorong oleh ketegangan yang terjadi di wilayah lautan tersebut, yang membuat stabilitas regional dan akses ke Laut China Selatan selalu akan menjadi kepentingan global. Sebelum masalah kedaulatan maritim dapat terpecahkan, maka perairan itu akan terus menghadapi sengketa geopolitik terkait perdagangan internasional yang berdampak pada ekonomi dunia. Hal ini dibuktikan dengan pengaruh dilema keamanan yang dialami oleh Vietnam akibat kedekatan geografis antara Vietnam dan Indonesia.

Terakhir, faktor lain pendukung hubungan Vietnam dan Indonesia adalah akses terhadap bahan baku. Dalam pemenuhan akan kebutuhan bahan baku dan kemudahan akses terhadap bahan baku diperlukan adanya kerja sama dan perdagangan antar negara. Ketergantungan kepada bahan baku inilah yang akan menjadi tantangan bagi Vietnam. Oleh karena itu, kerja sama yang terjalin antara Vietnam dan Indonesia terus berkembang dengan pesat di berbagai bidang politik, 
ekonomi, budaya, pendidikan bahkan pertahanan dan keamanan. Dalam beberapa tahun terakhir, perdagangan kedua negara mengalami kemajuan yang memuaskan. Pada tahun 2017 nilai perdagangan dua arah kedua negara mencapai $\$ 6,5$ miliar, dan pada bulan Juni 2018, Indonesia menempati peringkat ke-5 terbesar di antara negara-negara ASEAN dan peringkat ke-30 di antara negaranegara di seluruh dunia yang melakukan investasi di Vietnam. Investasi tersebut meliputi proyek-proyek yang sebagian besarnya adalah investasi pada sektor eksplorasi dan eksploitasi minyak dan gas, penambangan batu bara, perbankan, industri perhotelan, dan proses kayu sebanyak 71 buah (NhanDan, 2018).
Nilai perdagangan Vietnam terhadap Indonesia menjadi aspek yang sangat perlu diperhatikan. Dalam gambar 5 di bawah ini, terlihat bahwa nilai impor Vietnam terhadap Indonesia lebih besar dari nilai ekspor nya yaitu sebesar $\$ 3.587$ juta, dibanding dengan $\$ 3.228$ juta, atau setara dengan $53 \%$ dari nilai impor yang meliputi kertas, LPG, bahan kimia, hasil perikanan dan suku cadang motor, serta $47 \%$ dari nilai ekspor yang meliputi beras, clinker \& semen, tekstil \& benang, produk kimia, kopi dan plastik \& olahan plastik. Dalam perdagangan kedua negara tersebut, akses terhadap bahan baku sangat penting karena hal ini akan memudahkan pemenuhan kebutuhan domestik.

\section{NILAI PERDAGANGAN VIETNAM TERHADAP INDONESIA (2017)}

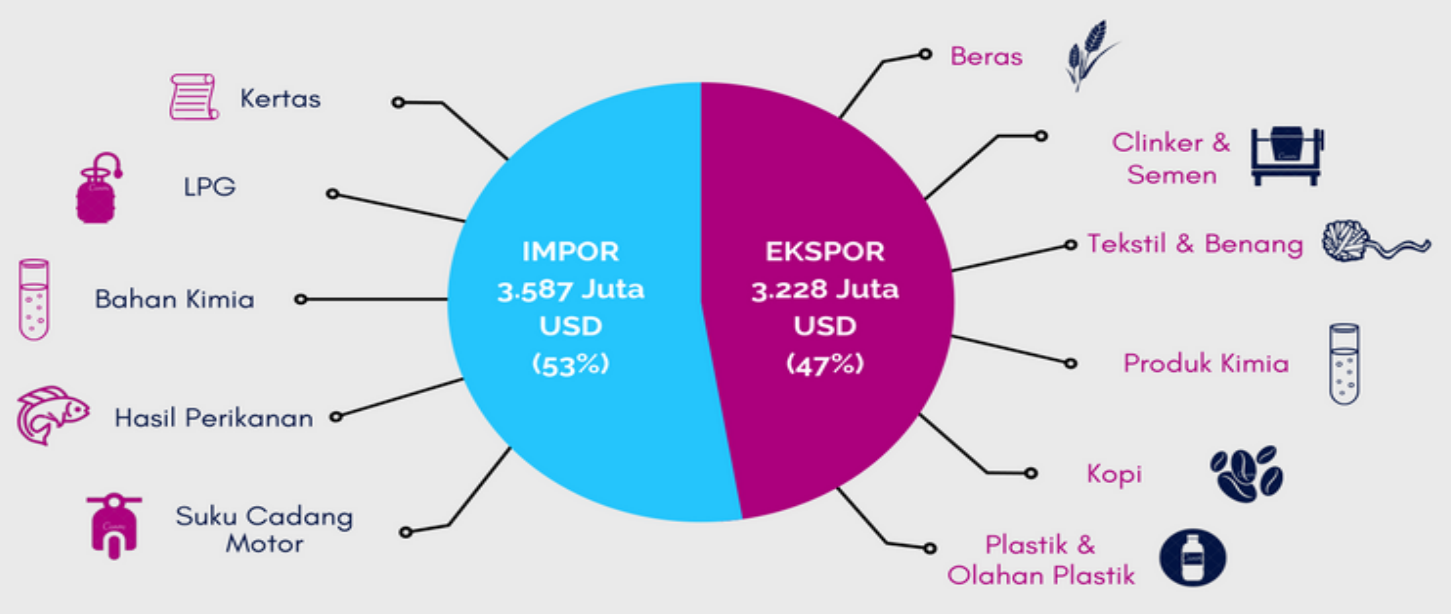

Sumber: Sekretariat Nasional ASEAN-Indonesia, 2017.

Gambar 5.

Nilai Perdagangan Vietnam terhadap Indonesia tahun 2017

Dari data yang ada, kebutuhan impor dan ekspor Vietnam terhadap Indonesia mengalami peningkatan pesat, seiring dengan peningkatan perekonomiannya dari keluarga kelas menengah ke atas, peningkatan penduduk terutama jumlah generasi muda dan perkembangan pariwisata, serta peluang investasi dari berbagai bidang seperti industri, telekomunikasi, retail, bahkan sampai pada pembangunan konstruksi dan manufaktur (Sekretariat Nasional ASEAN-Indonesia, 2017). Oleh karena itu, seiring dengan perkembangan dan peningkatan aktivitas perekonomiannya, Vietnam melihat bahwa tindakan secara agresif terhadap Indonesia, secara langsung akan berdampak buruk 
terhadap akses bahan baku, dan berakibat terhadap relasi dengan Indonesia.

Di lain sisi, hubungan diplomatik Vietnam dan Indonesia yang telah terjalin sejak tahun 1955 terus berkembang hingga saat ini. Bukan hanya dalam perekonomian dan perdagangan, lebih dari itu, bahwa kedua negara telah meningkatkan hubungannya, yang semula kemitraan komprehensif menjadi mitra strategis pada tahun 2013. Hubungan yang terjalin baik tersebut secara aktif berkontribusi pada perkembangan dan kemajuan kedua negara, dalam hubungannya terhadap perkembangan untuk perdamaian dan kemakmuran kawasan (Việt, 2020)

Gejolak-gejolak yang terjadi dalam hubungan bilateral kedua negara seringkali terjadi, namun secara keseluruhan hubungan kedua negara masih terjalin baik. Dalam hal politik, pertemuan rutin antara kedua negara sering dilakukan, antara lain pertukaran kunjungan di berbagai tingkat jabatan pemimpin-pemimpinnya. Pada sektor ekonomi, Indonesia merupakan mitra ekonomi Vietnam kedua terbesar di ASEAN dan sekaligus merupakan salah satu investor terbesar di Vietnam. Pada bidang keamanan dan pertahanan, kedua negara bekerja sama erat pada ASEAN Regional Forum (ARF) yang merupakan suatu wadah dialog dan diskusi tentang politik dan keamanan di kawasan, agar dapat selalu menyamakan pandangan antara negaranegara anggota ARF dalam mencegah serta memperkecil ancaman yang timbul antar negara kawasan. Dalam dunia pendidikan, lebih dari 200 siswa dari Vietnam belajar di Universitas Indonesia, dan jumlahnya meningkat setiap tahunnya. Pada bidang pariwisata, setiap tahunnya wisatawan Vietnam maupun Indonesia saling bertukar kunjungan. Jumlah wisatawan Indonesia yang berkunjung ke Vietnam berkisar antara 80.000 orang dan sekitar 50.000 wisatawan Vietnam berkunjung ke Indonesia (Việt, 2020).

Dalam kerja sama bilateral, kedua negara telah memprioritaskan dan membagi dalam tiga area kerja sama, yaitu sektor perdagangan dan investasi, sektor pertanian, serta sektor maritim/ perikanan (Kementrian Luar Negeri Republik Indonesia, 2015: 21). Hanya saja, pada saat ini, masalah terbesar yang terjadi dalam hubungan bilateral kedua negara adalah resolusi yang ditetapkan oleh para pemimpinya dalam kaitannya dengan ZEE. Kedua negara sepakat untuk terus menempuh jalan negosiasi agar dapat tercapai kata sepakat dalam hal penetapan batas wilayah dan batas kelola di dalam kawasan, yang sejalan dengan hubungan antarnegara yaitu atas dasar prinsipprinsip politik luar negeri RI dan hukum internasional yang berlaku, agar tercapai kesepakatan yang merupakan momentum bagi perkembangan hubungan bilateral kedua negara yang semakin mendalam.

\section{Pengaruh Kemampuan Material Ter- hadap Kebijakan Luar Negeri Vietnam}

Asumsi ketiga yang dikemukakan oleh Taliaferro dalam defensif realisme adalah material capabilities atau kemampuan material. Kemampuan material mendorong kebijakan luar negeri berdasarkan perhitungan dan persepsi para pemimpin. Kekuatan material dan perilaku negara memiliki korelasi langsung. Luas wilayah dan jumlah penduduk menjadi faktor penting karena merupakan fasilitator kebijakan luar negeri dan memiliki peran dalam operasi menjaga perdamaian. Luas wilayah dan jumlah penduduk yang tinggi dapat menghadirkan peluang untuk negara dalam konteks pertahanan negara. Indonesia merupakan negara terbesar dalam sisi geografis serta demografis dibandingkan dengan Vietnam. Vietnam dengan luas wilayah $331.210 \mathrm{~km}^{2}$ dan jumlah penduduk mencapai 96.491.146 jiwa berada jauh di bawah Indonesia yang memiliki luas wilayah sebesar 1.904.569 $\mathrm{km}^{2}$ dan populasi penduduk yang hampir tiga kali lipat penduduk Vietnam (Statisticstime, 2018). Dengan kondisi luas dan jumlah penduduk tersebut di atas, 
negara cenderung menyediakan dana yang berfokus pada bidang pertahanan negara dengan besaran yang beragam.

Grafik 3

Grafik Belanja Militer Vietnam, Indonesia dan China (juta USD), tahun 2014-2018

\section{Belanja Militer (juta US\$)}

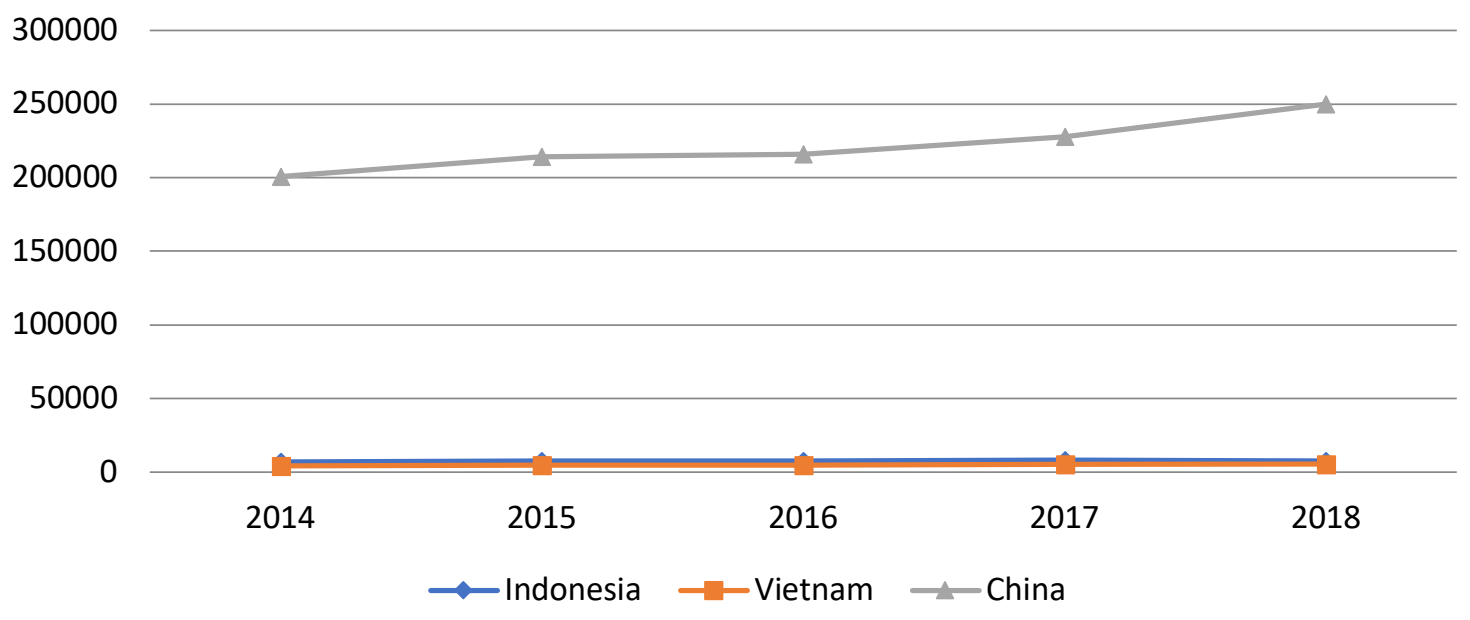

Sumber: Diolah oleh penulis dari The Stockholm International Peace Research Institute (SIPRI), 2018.

Gambar 6.

Grafik Belanja Militer Vietnam, Indonesia, dan China (juta US\$), tahun 2014-2018

Secara umum, Vietnam selalu meningkatkan belanja pertahanan dari tahun ke tahun, sejak tahun 2014 hingga tahun 2018. Indonesia pada tahun 2018 menghabiskan anggaran pertahanan sebesar \$7.437 juta, sedangkan Vietnam pada angka sebesar $\$ 5.500$ juta. Dilihat dari sektor pertahanan militer, posisi Vietnam berada di bawah Indonesia, sedangkan China menjadi negara super power yang berada jauh melampaui Indonesia dan Vietnam. Bahkan untuk tahun 2018, anggaran pertahanan China berada di angka $\$ 249.997$ juta dan terus mengalami peningkatan dalam kurun waktu empat tahun terakhir.
Selain alokasi untuk anggaran pertahanan, indikator lain yang juga dapat dijadikan sebagai dasar argumen adalah aspek kualitas dan kuantitas dari peralatan militer yang dimiliki oleh kedua negara. Saat ini Vietnam terus berupaya untuk selalu menambah armada angkatan bersenjatanya, hal ini dilakukan dalam upayanya untuk menghadapi dinamika yang terjadi di kawasan Laut China Selatan. Vietnam ingin memastikan bahwa kendali efektif yang berada di sana adalah bagian dari sebuah pertahanan (Sulistyo, 2017: 28). 
Tabel 2.

Kekuatan Militer Vietnam dan Indonesia

\begin{tabular}{lcc}
\hline Land Forces & Vietnam & Indonesia \\
\hline Tanks & 1509 & 408 \\
\hline Armoured fighting vehicles & 2380 & 1249 \\
\hline Total aertillery & 2524 & 356 \\
\hline Self-propelled artillery & 280 & 141 \\
\hline Rocket artillery & 1094 & 86 \\
\hline Air Forces & & Indonesia \\
\hline & Vietnam & 420 \\
\hline Total aircraft & 274 & 11 \\
\hline Fighter aircraft & 37 & 64 \\
\hline Multirole aircraft & 24 & 15 \\
\hline Attack aircraft & 36 & 164 \\
\hline Helicopters & 145 & Indonesia \\
\hline Navy & & 147 \\
\hline & Vietnam & 0 \\
\hline Total naval & 173 & 0 \\
\hline Aircraftcarriers & 0 & 8 \\
\hline Destroyers & 0 & 24 \\
\hline Frigates & 7 & 5 \\
\hline Corvettes & 23 & \\
\hline Submarines & 6 & \\
\hline Sul & & \\
\hline
\end{tabular}

Sumber: Diolah dari Armedforces, 2019.

Pada tabel 2 di atas, dapat dilihat bahwa Vietnam memiliki keunggulan dari segi kuantitas terhadap armada militer angkatan darat dan angkatan lautnya. Sementara itu, Indonesia memiliki keunggulan pada armada angkatan udaranya. Seiring dengan pertumbuhan ekonomi kedua negara, maka modernisasi terhadap pasukan pertahanan dilakukan secara terus menerus oleh kedua negara, agar bertujuan untuk mencapai standarisasi sistem aliansi dan juga sebagai bentuk antisipasi terhadap segala ketidakpastian yang mungkin terjadi.

Secara umum, kapabilitas material yang dimiliki Indonesia, mulai dari luas wilayah dan jumlah penduduk serta anggaran belanja pertahanan sampai dengan kualitas serta kuantitas persenjataan militer cukup tinggi, bahkan dalam beberapa aspek pertahanan, Indonesia jauh lebih unggul dibandingkan dengan Vietnam. Keunggulan kapabilitas material yang dimiliki Indonesia inilah yang mendasari persepsi dan kebijakan Vietnam dalam merespon Indonesia terkait kebijakan IUU Fishing STV.

\section{Interelasi Politik Dalam Negeri dan Orientasi Kebijakan Luar Negeri Vietnam dalam Merespon Kebijakan IUU Fishing Indonesia}

Dalam asumsi terakhir yang di kemukan oleh Taliaferro dikatakan bahwa politik dalam negeri akan mempengaruhi kebijakan suatu negara. Interaksi yang terjadi antara dua negara yaitu Vietnam dan Indonesia karena adanya interaksi dua arah 
yang berlandaskan identitas dan kepentingan masing-masing negara. Hal ini dapat dilihat berdasarkan kebijakan luar negeri kedua negara tersebut. Begitu pun yang terjadi pada respon Vietnam terhadap kebijakan penenggelaman kapal oleh Indonesia.

Pada tahun 1986, Vietnam menerapkan kebijakan Doi Moi (Renovation) sebagai hasil dari keputusan Kongres ke-6 Partai Komunis Vietnam. Di mana kebijakan ini menyasar pergeseran orientasi ekonomi Vietnam sebagai negara sosialis menuju keterbukaan pasar, tanpa meninggalkan ideologi komunisme. Untuk mengakomodasi pergeseran orientasi ini, "the politburo issued Resolution 13 in 1988, which called for the adoption of a multidirectional foreign policy focused on economic development and creating "more friends and less enemies" (Thayer di dalam Chapman, 2017). Dalam hal ini, kebijakan luar negeri Vietnam secara lebih lentur menyasar diversifikasi hubungan internasional melalui kerja sama Vietnam dengan berbagai negara dunia secara lebih intensif dan ekstensif.

Tidak hanya diversifikasi kerja sama bilateral, melalui prinsip multilateralization, Vietnam juga menyasar integrasi Vietnam dengan berbagai institusi-institusi regional maupun global. Kecenderungan ini dijelaskan oleh Nicholas Chapman (2017) sebagai berikut,

Vietnam significantly bolstered its diplomatic relations, moving from having diplomatic relations with just 23 countries in 1985 to 163 by 1995. It momentously joined the Association of Southeast Asian Nations (ASEAN) in 1995, the Asia-Pacific Economic Cooperation (APEC) in 1998 and applied for World Trade Organization (WTO) membership in 2001.

Selain itu, reformasi ekonomi yang telah membawa kemajuan luar biasa terhadap Vietnam. Sejak tahun 1990, Vietnam menikmati pertumbuhan ekonomi lebih dari 6\% setiap tahun (Thayer, 2017). Pergeseran orientasi kebijakan luar negeri Vietnam sangat penting dalam rangka menghadapi ancaman kebangkitan China, yang mana Vietnam memiliki masalah terkait sengketa wilayah di LCS. Resolusi No.13 pada tahun 1988 yang meluncurkan kebijakan Multidirectional Foreign Policy bagi Vietnam, juga memuat upaya strategis dalam menghadapi China dengan memperkenalkan definisi kepentingan nasional untuk Vietnam. Terutama pasca normalisasi hubungan antara Vietnam-China, kedua negara sosialis ini menyadari bahwa mereka memiliki kepentingan nasional yang berbeda (Thayer, 2017).

Dapat dilihat bahwa kebijakan luar negeri Vietnam telah mengalami pergeseran dari waktu ke waktu. Sepanjang sejarah yang telah dialami Vietnam sangat mempengaruhi politik dalam negerinya. Secara historis, Vietnam telah melalui perjuangan melawan kolonialisme pada masa berdirinya Vietnam sebagai sebuah negara. Vietnam telah menderita akibat perang di masa lalu. Banyak korban tewas yang berasal dari perwira, prajurit dan angkatan bersenjata yang belum teridentifikasi. Kemudian dampak lain yang dirasakan adalah efek kesehatan yang berkepanjangan bagi jutaan orang, menghancurkan lebih dari setengah dari daerah hutan alami dan terkontaminasi lingkungan parah di banyak tempat. Ribuan orang Vietnam telah menghadapi bahaya bom, ranjau, dan meriam yang tidak meledak dan tersisa dari perang (Ministry of National Defence, 2019: 15)

Masyarakat Vietnam sangat melekat akan pentingnya mempertahankan stabilitas internal bersama dengan menjalin persahabatan dengan negara-negara lain untuk pembangunan nasionalnya (Ministry of National Defence, 2019: 6). Pemerintah dan masyarakat mencurahkan banyak upaya dalam bekerja sama dengan negaranegara dan organisasi internasional untuk mengatasi dampak perang untuk berkontribusi untuk melindungi lingkungan hidup dan kesehatan masyarakat serta memastikan keamanan bagi pembangunan sosial dan ekonomi. 
Dalam menghadapi tantangan ataupun sengketa dengan negara lain, terutama dengan Indonesia sebagaimana yang dibahas pada tulisan ini. Vietnam sangat menghargai kemerdekaan, kedaulatan, persatuan teritorial dan integritas, dan kepentingan nasional sebagaimana yang disediakan dalam hukum internasional. Vietnam dengan tegas dan konsisten berjuang untuk menyelesaikan semua perselisihan melalui cara damai atas dasar hukum dan praktik internasional. Sebagaimana tertuang dalam Buku Putih Vietnam tahun 2019 "Viet Nam resolutely and consistently struggles to settle all disputes and differences through peaceful means on the basic of international law and practices" (Ministry of National Defence, 2019: 29). Ancaman dan tantangan yang dialami Vietnam terkait kedaulatan kewilayahan berkaitan dengan sengketa di Laut China Selatan yang nantinya akan memicu konflik dengan negara-negara besar seperti China.

Menurut buku putih pertahanan Vietnam, "Vietnam consistently realizes the foreign guideline of independence [and] selfreliance..." (Ministry of National Defence, 2009). Secara konsisten dua nilai yang dipegang teguh oleh Vietnam ini tercermin di dalam kebijakan pertahanannya yang acap disebut "Three no's': Vietnam consistently advocates neither joining any military alliances nor giving any other countries permission to have military bases or use its soil to carry out military activities against other countries." (Ministry of National Defence, 2009: 21-22). Tiga prinsip tersebut menghindarkan Vietnam untuk terjebak di dalam rivalitass kekuatan besar yang acap merongrong keberadaan negara-negara Asia Tenggara, terutama Amerika Serikat dan China.

Kemerdekaan dan kemandirian sebagai identitas utama Vietnam sebagai negara berdaulat sangat tercermin di dalam narasi buku putih pertahanan Vietnam yang diterbitkan pada tahun 2009. Seperti dalam kalimat berikut:
As a nation having experienced wars for national independence and freedom, Vietnam thoroughly respects other countries' independence, sovereignty, unity, territorial integrity and national interests on the basis of fundamental principles of the United Nations Charter and international laws. At the same time, Vietnam demands that its independence, sovereignty, unity, territorial integrity and national interests must be respected by other countries. Vietnam advocates against the military use of force first in international relations but is ready to resolutely fight against all aggressive acts (Ministry of National Defence, 2009: 19).

Integritas serta kesatuan teritorial sebagai representasi dari independensi Vietnam sebagai negara berdaulat sangat nampak di dalam pemahaman terkait identitas negara yang telah berkali-kali memenangkan pertempuran dengan bermacam aggresor yang mengancam keberadaan Vietnam sebagai negara berdaulat. Oleh karenanya, pada koridor pertahanan nasional, buku putih negara tersebut memperteguh pentingnya independence dan self-reliance sebagai identitas negara dalam kalimat "Vietnam's national defence is always closely linked to the CPV and the State's guideline of independence, self-reliance, peace, cooperation and development in external affairs, and the foreign policy of openness, multilateralization and diversification in international relations" (Ministry of National Defence, 2009: 21).

Oleh karena itu, analisis ini dapat merangkum bahwasannya politik dalam negeri dapat mempengaruhi respons yang dipilih oleh Vietbam terhadap Indonesia, yakni berdasarkan pada faktor historis yang dialami Vietnam, masyarakat yang menginginkan stabilitas internal berdasarkan jalinan persahabatan dengan negara lain, serta dari sisi kebijakan luar negeri Vietnam yang mengedepankan perdamaian dan hukum internasional dalam menghadapi ancaman dan tantangan. 


\section{KESIMPULAN}

Vietnam di era dinamika keamanan maritim Asia Tenggara kontemporer mengalami ketegangan dan beberapa isu karera menguatnya sikap asertif Indonesia terkait IUUF. Dengan mengacu pada empat asumsi dalam realisme defensif, seperti yang di kemukakan oleh Talliaferro, diketahui bahwa variabel struktural akan membentuk suatu hasil internasional dan juga kebijakan luar negeri suatu negara. Dengan logika yang di uraikan oleh Talliafero, maka analisis mengenai respons Vietnam tersebut dapat didasarkan pada keempat asumsi tersebut. Oleh karena itu akan terdapat empat buah kesimpulan dari hasil penelitian ini.

Pertama, dapat disimpulkan bahwa Vietnam mengalami dilema keamanan dan dilema keamanan ini tidak berfokus pada Indonesia saja, melainkan lebih banyak disebabkan oleh pengaruh daripada China. Kedua, terjadinya konflik perairan yang kompleks antara Vietnam, Indonesia

\section{DAFTAR PUSTAKA}

\section{Buku \& Jurnal}

Alghifari, F., \& Letticia, R.N.O. (2016). Analisis Teori Offense-Defense Terhadap Reformasi Kebijakan Pertahanan Jepang Dalam Dinamika Keamanan di Asia Timur. Jurnal Politik Internasional, 18(1), 18-33.

Creswell, J. (2013). Research Design: Qualitative, Quantitative, and Mixed Methods Approached $4^{\text {th }}$ Ed. US: SAGE Publication.

Donnelly, J. (2000). Realism and International Relations.UK: Cambridge University Press.

Glaser, C.L., \& Kaufmann, C. 1998. What is the offense-defense balance and can we measure it? (Offense, Defense, and International Politics). International Security, 22(4), 1-23.

Jervis, R. (1978). Cooperations Under the Security Dilemma. Cambridge University Press, 30(2), 167-214. maupun China dikawasan tersebut, didasarkan atas offense-defense balance, kedekatan geografis serta berpotensi mempengaruhi akses terhadap bahan baku pada negara-negara di sekitar kawasan tersebut. Ketiga, jika dilihat dari kapabilitas material antara Vietnam dan Indonesia, secara umum, Indonesia lebih unggul daripada Vietnam dilihat dari luas wilayah, jumlah penduduk, anggaran belanja pertahanan sampai dengan kualitas dan kuantitas dari persenjataan militer yang dimiliki oleh kedua negara. Keempat, jika dilihat dari politik dalam negerinya, Vietnam memiliki kecenderungan untuk tetap menjaga hubungan baik dengan Indonesia yang telah terjalin selama ini mengingat bahwa Indonesia adalah mitra penting dan satu-satunya mitra strategis bagi Vietnam di kawasan Asia Tenggara dan secara konsisten berjuang untuk menyelesaikan semua perselisihan melalui cara damai atas dasar hukum dan praktik internasional.

Juned, M., Samhudi, G.R., \& Lasim, R.A. (2019). The Impact Indonesia's Sinking of Illegal Fishing Ships on Major Southeast Asia Countries. International Journal of Multicultural and Multireligious Understanding, 6(2), 62-76.

Kantaprawira, R., Bainus, A., \& Kusumawardhana, I. (2018). The Unbreakable Relations between Indonesia Vietnam Under "Sink the Vessels" Policy: A Complex System Approach. Journal of ASEAN Studies, 6(2), 155-178.

Kementrian Luar Negeri Republik Indonesia. (2015). Diplomasi Indonesia 2014. Indonesia: Direktorat Informasi dan Media, Direktorat Jenderal Informasi dan Diplomasi Publik, Kementrian Luar Negeri Republik Indonesia.

Sulistyo, I. (2017). Dinamika Persenjataan di Asia Tenggara. Andalas Journal of International Studies, 6(1), 17-36. 
Taliaferro, J.W. (2015). Security Seeking Under Anarchy: Defensive Realisme Revisited. The MIT Press, 25(3), 128161.

\section{Makalah dan Dokumen Resmi}

Ministry of National Defence. (2019). Vietnam National Defence. Socialist Republic of Vietnam

Muhamad, S.V. (2014). Peningkatan Kekuatan Militer di Kawasan dan Peran ASEAN Regional Forum. Pusat Pengkajian, Pengolahan Data dan Informasi. Vol.VI, No.06/II/P3DI/Maret/2014

Ojamaa, P. (2018). Research for PECH Committee-Fisheries in Vietnam. Policy Departement for Structural and Cohesion Policies Directorate-General for Internal Policies, European Union

Undang-Undang Nomor 45 Tahun 2009 tentang Perubahan atas UndangUndang Nomor 31 Tahun 2004 tentang Perikanan.

\section{Internet}

Ambari, M. (2019). "Penenggelaman Kapal Pencuri Ikan Jalan Keluar Terbaik Bagi Indonesia." Diakses dari https://www.mongabay.co.id/2019/ 05/14/penenggelaman-kapalpencuri-ikan-jalan-keluar-terbaikbagi-indonesia/.

Armed Forces.eu. (2019). "Military Power of Vietnam \& Indonesia." Diakses dari https://armedforces.eu/compare/co untry_Vietnam_vs_Indonesia.

BBC. (2018). "Tenggelamkan Kapal: Indonesia 'tak boleh' Lakukan 'tanpa sidang', Kata Vietnam." Diakses dari https://www.bbc.com/indonesia/tre nsosial-42653898.

Elnizar, E. (2017). “Begini Penjelasan Hukum atas Penenggelaman Kapal Terlibat Illegal Fishing." Diakses dari https://www.hukumonline.com/beri ta/baca/lt59f149581edd7/beginipenjelasan-hukum-atas- penenggelaman-kapal-terlibat-illegalfishing/.

FAO. (2019). "Illegal, Unreported and Unregulated (IUU) fishing." Diakses dari http://www.fao.org/iuufishing/background/what-is-iuufishing/en/.

Lintner, B. (2019). "China, Vietnam Will Never Agree on South China Sea." Diakses dari https://www.asiatimes.com/2019/1 1/article/china-vietnam-will-neveragree-on-south-china-sea/.

NhanDan (2018). "Strengthening Vietnam Indonesia Strategic Partnership." Diakses dari https://en.nhandan.com.vn/politics/ editorial/item/6593902strengthening-vietnam\%E2\%80\%93-indonesia-strategicpartnership.html.

Parameswaran, P. (2015). "Vietnam 'Deeply Concerned' by Indonesia's War on Ilegal Fishing." Diakses dari https://thediplomat.com/2015/08/v ietnam-deeply-concerned-byindonesias-war-on-illegal-fishing/.

Sekretariat Nasional ASEAN-INDONESIA. (2017). "Vietnam." Diakses dari http://setnas-asean.id/potensi-danpeluang-bisnis/read/vietnam.

SIPRI. (2019). "Military expenditure by country, in constant (2017) US\$m., 1988-2018." Diakses dari https://www.sipri.org/sites/default/ files/Data\%20for\%20all\%20countrie s\%20from\%201988\%E2\%80\%9320 18\%20in\%20constant\%20\%282017 \%29\%20USD\%20\%28pdf\%29.pdf.

Statisticstime. (2018). "List of Asian countries by Population." Diakses dari http://statisticstimes.com/demograp hics/asian-countries-bypopulation.php.

Thu, H.L. (2019). "Vietnam Draws Lines in the Sea ." Diakses dari https://foreignpolicy.com/2019/12/ 06/vietnam-south-china-sea-unitedstates-draws-lines-in-the-sea/. 
Việt, T. (2020). "60th anniversary of Vietnam - Indonesia established diplomatic relations: Strategic Partnership will help to elevate the ASEAN Community." Diakses dari https://vnembassyjakarta.mofa.gov.vn/enus/News/EmbassyNews/Pages/K\%E 1\%BB\%B7-ni\%E1\%BB\%87m-60n\%C4\%83m-ng\%C3\%A0yVi\%E1\%BB\%87t-Nam$\%$ E2\%80\%93-Indonesia-
thi\%E1\%BA\%BFt-1\%E1\%BA\%ADpquan-h\%E1\%BB\%87ngo\%E1\%BA\%A1i-giao.aspx.

Wivell, B. (2015). "The Case for ASEAN Military Integration." Diakses dari https://intpolicydigest.org/2015/10 /17/the-case-for-asean-militaryintegration/.

Wijaya, C. (2019). BBC. Diakses dari https://www.bbc.com/indonesia/ind onesia-48103607. 